\title{
The importance of investing in a public health system: evidence from COVID-19 mortality
}

\section{Pulapre Balakrishnan $^{1}$. Sreenath K. Namboodhiry ${ }^{2}$}

Accepted: 5 June 2021 / Published online: 4 July 2021

(c) Editorial Office, Indian Economic Review 2021

\begin{abstract}
Mortality due to COVID-19 has varied across the states of India. We exploit this history to investigate the possible role of health policy in the outcome. Using three different measures of the death rate, we find to a varying degree, evidence that the level of public expenditure on health has made a difference to the state-wise mortality rate. Based on this, we proceeded to analyse the expenditure pattern in the states. The average level of expenditure on health is found to be low both of itself and in relation to spending by governments in South and Southeast Asia. In much of the territory of India spending on the police exceeds that of spending on health. Furthermore, richer states spend relatively less on it, implying that spending on health is a matter of choice for states rather than dictated by financial constraints. Two conclusions follow. First, some of the mortality from COVID-19 is policy induced, and therefore was avoidable. Second, though the evidence is drawn from the experience with COVID-19, we may assume that assuring health security to the Indian population would require a radical restructuring of the spending priorities of the states.
\end{abstract}

Keywords Public health policy $\cdot$ COVID-19 $\cdot$ India $\cdot$ Developing countries

JEL Codes H51 · I15 · I18

Sreenath K. Namboodhiry

sreenathnamboothiry@gmail.com

1 Department of Economics, Ashoka University, Sonipat, Haryana 131028, India

2 Economics Area, Indian Institute of Management Kozhikode, Kunnamangalam, Kerala 673570, India 


\section{Introduction}

The experience with COVID-19 in India, in particular the surging ${ }^{1}$ cases of infection and death during the second wave that commenced in April 2021, has brought home the relevance of health security as a goal of public policy. In the case of a communicable disease epidemic, health security ensures that a population is immune to infection and if they do contract the disease they remain immune from death. But health security can and should be construed more generally as protection from all forms of medical threat to human life and well-being. Even as we are battling the corona virus, it is necessary to look ahead to a time when it is under control and are we able to provide health security more generally, that is across the range of medical conditions that afflict the population. This article is an attempt to identify the factors that contribute to health security using data from the COVID-19 experience of India.

The virus underlying a communicable disease is invasive. As an epidemic engulfs a population, the numbers involved are so great that the private sector is unlikely to be able muster the resources necessary for treating the infected. Only the state has the access to finance to respond at the necessary scale and the legal authority to enforce COVID-appropriate behaviour on the population. For these reasons, we would expect that the public sector would have a significant role in influencing the mortality due to COVID-19. In this article, we investigate whether health policy and the availability of medical infrastructure in the public sector has played such a role. Our method is based on the following history. While the recorded death rate from COVID-19 is lower in India than in BRICS, there is a significant variation within the country. ${ }^{2}$ For instance, on March 31 , the range for 'deaths per million' for India's 30 states was 453 while the mean was 128 , indicating considerable dispersion. ${ }^{3} \mathrm{We}$ exploit this variation in mortality across India's states to infer the role of public health policy and infrastructure in determining death from COVID-19. Guided by the statistical findings, we analyse the pattern of public health expenditure across the states of India and evaluate its adequacy through an international comparison of health policy and COVID-19 mortality.

\footnotetext{
${ }^{1}$ Balakrishnan is with Ashoka University, Sonipat and the Indian Institute of Management, Kozhikode. Namboodhiry was with the Indian Institute of Management, Kozhikode when the research for this article was undertaken. We thank these institutions for support. An earlier version of this paper was presented at the Society for Economics Research in India (SERI) Workshop held online over September 18-19, 2020 and the 9th Annual Conference of Indian Health Economics and Policy Association (IHEPA) held online on January 22, 2021. At various stages of the development of this article we have benefitted from the comments and advice of Bhaskar Dutta, Gautam Menon, Aaditya Dar, Parikshit Ghosh, Bharat Ramaswami, M.Parameswaran, M.Suresh Babu, S. Irudayarajan, Deepak Dayanithy and, above all, J.V.Meenakshi. Errors, if any, are our responsibility.

${ }^{2}$ For the international data see https://ourworldindata.org/coronavirus-source-data; for India see Table 11 in the Appendix.

${ }^{3}$ See Table 12 of the Appendix for the state-wise distribution.
} 


\section{Measuring mortality from COVID-19 in India}

The first task for a researcher studying death from any disease would be to decide on the measure of mortality to be adopted. Two measures encountered globally are the Infection Fatality Rate and the Crude Death Rate. The first is the ratio of deaths to the number of infected persons. Assuming that deaths are properly counted, the issue becomes one of the denominator to be used. As testing the entire population is next to impossible for countries as large as India a sero-survey may be conducted to first establish the proportion of the population infected and this information used to get an estimate of the total number of infected persons. In the absence of serosurveys, the number of cases of infection detected through testing is usually taken as the denominator. This gives the Case Fatality Rate (CFR). It is easy to see that, even when deaths are reported accurately, the CFR is affected by the progress made on testing the population for the existence of the virus. In a cross-section study such as the one we intend to undertaking here, if the actual cases of infection is the same but the rate of testing varies across the sample, this measure would show a higher death rate for those Indian states that test less. We have some evidence that the extent of testing of the population varies between states, and over time within a state, leaving CFR a less than ideal measure. Nevertheless, it is widely used globally and this leads us to retain it as one of the measures of mortality in our investigation. We do, however, make an adjustment. Most often CFR is calculated as the number of deaths as a percentage of the number of confirmed cases of infection, both measured on the same date. This, however, is inappropriate as the incubation period of the virus is believed to be approximately 2 weeks. Now, the appropriate denominator would be the number of confirmed cases of infection a fortnight prior to the date for which deaths are counted. The CFR computed for this study reflects this consideration.

This leaves the crude death rate, which we denote as $\mathrm{DR}(\mathrm{C})$, as an alternative measure of fatality. This measure is simply the ratio of deaths to the population (in millions). It would appear that this is a more straightforward measure than the CFR, cutting straight to the population, thus avoiding the need to count the cases of infection. However, while we have so far implicitly assumed in our discussion of the calculation of the CFR that deaths are properly counted it need not always be the case. It is well known that in India not all deaths are registered with the civil authorities and even when they are registered the cause of death is not always medically certified. When this is so, the crude death rate will no longer suffice. Medical practitioners (Shewade \& Parameswaran, 2020) have proposed an adjustment to account for both the under-reporting of death and the absent medical certification of the cause of death (MCCD). This is to scale up the number of reported COVID-19 deaths by the inverse of the product:

$$
\frac{\text { Registered Deaths }}{\text { Total Deaths }} * \frac{\text { MCCD }}{\text { Registered Deaths }} \text {. }
$$

While we see that this is an imaginative innovation in the context, we believe that the resulting figure, which we term the Estimated Death Rate-DR(E), should be treated with caution. The reason for this is that the adjustment assumes 
the same proportions, of registered to total deaths and medically certified deaths to registered deaths, for COVID-19 as for all other causes of death in India. This is questionable. Surveillance by both the public health administration and society during a pandemic very likely ensures that deaths from COVID-19 cannot evade medical certification or registration to the same extent as other cases of death. On the question of under-reportage of deaths, it should be noted that community health specialists have argued that the view that deaths are systematically underreported in India may be based more on predilection than fact.

We have computed DR(E) for all states and present it beside the Crude Death Rate for comparison in Table 12 of the Appendix. Note that the difference is considerable. For instance, the Estimated Death Rate exceeds the Crude Death Rate by a factor of 9 in Kerala. This appears implausibly high to us given that the surveillance of COVID-19 infection may be expected to be high in this state given the political awareness of the population and the relatively advanced public health system of the state. Nevertheless, in our empirical investigation, we worked with both the crude and the estimated death rates to address the perception that deaths may have been under-reported.

The coverage of this study is all of India except the Union Territories, which have been excluded because some of the necessary data was not available. The mortality data are cumulative deaths as on March 31, 2021. ${ }^{4}$ The rest of the data are that currently available at the time of writing.

\section{Income, public health expenditure and infrastructure: an investigation}

We hypothesise that the mortality from COVID is related to the robustness of the public health system. A central element of the health system is the available infrastructure ranging from hospitals to the sufficient presence of medical personnel. The latter would include, in addition to doctors, health workers in general. But a health system also requires co-ordination, acutely so in an emergency when scarce resources need not only to be optimally allocated but to be made available at all times. Logistics are crucial to the achievement of this goal. An effective health system would then require to be backed by resources. Public expenditure on health now emerges as a likely determinant of health outcomes other than health infrastructure. In our empirical exercise, therefore, we investigate the role of both medical infrastructure in the public sector and public expenditure on health in explaining the variation in mortality from COVID-19 across the states of India. Finally, as the states of India vary considerably according to their per capita income, we also investigate whether this has made a difference to the observed outcome.

\footnotetext{
${ }^{4}$ See Tables 11 and12 in the Appendix.
} 


\subsection{Results}

\subsubsection{CFR}

3.1.1.1 Rank correlation We commenced by computed rank correlation between state-wise CFR, public expenditure on health, per capita income and some obvious items of health infrastructure. A significant rank correlation is evident between mortality and health expenditure as a share of state gross domestic product (henceforth HE/GDP) but not the other variables considered. States that have spent more on health have lower mortality from COVID-19. In addition, it is found that expenditure in relation to GDP that matters and not per capita health expenditure. A possible reason why individual items of infrastructure do not seem to matter may be that the ability to contain the spread of infection and treat the infected depends on a complex of inputs. For example, we can see that the presence of hospitals and doctors does not matter when there is limited oxygen supply or, even when oxygen is available, the logistics fails to maintain the supply chain. For this reason, one would expect that health expenditure in relation to GDP is the best measure of capacity to respond in a pandemic. Finally, it may be noted that, though it is not statistically significant, the rank correlation between mortality and per capita income is actually positive. Clearly income has not served as a shield against the virus (Table 1).

3.1.1.2 Regression analysis We next undertook a regression analysis. Initially, mortality was regressed on both measures of health expenditure, the two items of health infrastructure - hospitals, beds - and the number of doctors, all in per head of the population. Among indicators of public expenditure, there was a statistically significant relationship only between mortality and public health expenditure as a share of GDP. The number of doctors were not significant in any regression. Both the indicators of physical infrastructure were significant in the case of DR(C) but not for CFR. The regressions are presented in Tables 2 and 3. When evaluating the finding that individual items of health infrastructure are found not to be statistically significant in one case, it ought to be borne in mind that public expenditure on health and the other variables under consideration here are likely to be related. ${ }^{5}$ In a sense, public health expenditure subsumes physical infrastructure while, in addition, creating crucial capacities for the health system, a point that we shall return to when summarising the results of our statistical exercise.

Based on the results thus far, in the following stage, the investigation focussed on the relationship between mortality and health expenditure as a share of GDP with and without controls in alternate runs. The three controls included were the extent of urbanisation in a state, the percentage of the population over 60, and income. Internationally, both population density (Coşkun et al. 2020) and the age profile of the population (Bonanad et al., 2020; Mallapaty, 2020) have been flagged as factors responsible for the spread of COVID-19 and mortality from the infection. While we

\footnotetext{
5 For instance, in our sample, there is rank correlation between public health expenditure and the number of doctors and hospitals per head of the population, though at the $10 \%$ level of significance.
} 
Table 1 Rank correlation (CFR)

\begin{tabular}{llllll}
\hline Spearman's rho & \multicolumn{5}{l}{} \\
\hline & HE/GDP & $\begin{array}{l}\text { Per capita } \\
\text { public health } \\
\text { expenditure }\end{array}$ & $\begin{array}{l}\text { Per capita } \\
\text { income }\end{array}$ & $\begin{array}{l}\text { Population served } \\
\text { by one government } \\
\text { allopathic doctor }\end{array}$ & $\begin{array}{l}\text { Population } \\
\text { served by one } \\
\text { government } \\
\text { hospital }\end{array}$ \\
\hline $\begin{array}{l}\text { Correlation coef- } \\
\text { ficient }\end{array}$ & $-0.417 *$ & -0.065 & 0.282 & -0.008 & 0.186 \\
$\begin{array}{l}\text { Sig. (2-tailed) } \\
\mathrm{N}\end{array}$ & 0.022 & 0.732 & 0.131 & 0.966 & 0.324 \\
& 30 & 30 & 30 & 30 & 30
\end{tabular}

*Correlation is significant at the 0.05 level (2-tailed)

retain the age profile of the population as a control we chose to replace population density with the extent of urbanisation. This is motivated by our reading of the evidence for India, where states with low density yet had high mortality very likely as they had several highly urban conglomerations. Maharashtra is the best example of this pattern. The definition of urbanisation is given in the Appendix.

Before proceeding to the regressions with controls, we address the question whether public expenditure continues to play a determining role even in the presence of a private health service, which has a substantial presence in some parts of the country. The results presented in Table 4 attest this. HE/GDP continues to be statistically significant in the presence of the principal indicators of infrastructure in the private sector. ${ }^{6}$ It suggests that the public sector has had a role beyond just the provision of infrastructure.

In Table 5 are presented regressions of CFR with controls. Health expenditure is significant at the five percent level when entered on its own-Model 1-but no longer so in the presence of controls-Model 2. However, as none of the controls are significant either. We can confidently reject Model 2, for which the $R$-squared drops even with more variables added. The maintained hypothesis that public health expenditure is a determinant of mortality may, therefore, be accepted. It would be appropriate to speak of 'determination' in the context for, due to the non-availability of contemporaneous data, we relied on health expenditure data for 2018-2019. As the mortality data is for 2021 endogeneity can be ruled out.

Finally, for a picture of how the states are arranged in terms of mortality in this case, CFR and public health expenditure, a cross-plot is provided in Fig. 1. The relationship is unmistakably inverse.

\footnotetext{
${ }^{6}$ Note that the measure of mortality in Table 4 is CFR. As the results were qualitatively identical when $\mathrm{DR}(\mathrm{C})$ was used instead they are not reported here. They are available from the authors upon request.
} 
Table 2 Regression-mortality and public health infrastructuredependent variable is CFR

Table 3 Regression-mortality and public health infrastructuredependent variable is DR (C)

\begin{tabular}{|c|c|c|c|c|c|}
\hline \multirow{2}{*}{\multicolumn{2}{|c|}{ Model }} & \multicolumn{2}{|c|}{ Coefficients } & \multirow[t]{2}{*}{$t$} & \multirow[t]{2}{*}{ Sig. } \\
\hline & & $B$ & Std. error & & \\
\hline \multirow[t]{3}{*}{1} & (Constant) & 1.685 & 0.204 & 8.275 & 0.000 \\
\hline & HE/GDP & -0.310 & 0.124 & -2.510 & $0.018^{*}$ \\
\hline & OLS, $N=30$, adj & ted $R$-Squar & $\mathrm{d}=0.155$ & & \\
\hline \multirow[t]{5}{*}{2} & (Constant) & 1.892 & 0.289 & 6.543 & 0.000 \\
\hline & HE/GDP & -0.335 & 0.130 & -2.572 & $0.016^{*}$ \\
\hline & $\begin{array}{l}\text { Population } \\
\text { served by one } \\
\text { government } \\
\text { hospital }\end{array}$ & $7.207 \mathrm{E}-7$ & 0.000 & 0.414 & 0.682 \\
\hline & $\begin{array}{l}\text { Population } \\
\text { served by one } \\
\text { government } \\
\text { hospital bed }\end{array}$ & 0.000 & 0.000 & -1.579 & 0.126 \\
\hline & OLS, $N=30$, adj & ted $R$-squar & $d=0.170$ & & \\
\hline
\end{tabular}

$* P<0.05$

\begin{tabular}{|c|c|c|c|c|c|}
\hline \multicolumn{2}{|c|}{ Model } & \multicolumn{2}{|c|}{ Coefficients } & \multirow[t]{2}{*}{$t$} & \multirow[t]{2}{*}{ Sig. } \\
\hline & & $B$ & Std. error & & \\
\hline \multirow[t]{3}{*}{1} & (Constant) & 195.924 & 36.129 & 5.423 & 0.000 \\
\hline & HE/GDP & -49.638 & 21.923 & -2.264 & $0.032 * *$ \\
\hline & OLS, $\mathrm{N}=30$, adj & sted R-squa & $e d=0.125$ & & \\
\hline \multirow[t]{5}{*}{2} & (Constant) & 220.901 & 46.461 & 4.755 & 0.000 \\
\hline & HE/GDP & -48.293 & 20.947 & -2.306 & $0.029 * *$ \\
\hline & $\begin{array}{l}\text { Population } \\
\text { served by one } \\
\text { government } \\
\text { hospital }\end{array}$ & 0.001 & 0.000 & 1.882 & $0.071 *$ \\
\hline & $\begin{array}{l}\text { Population } \\
\text { served by one } \\
\text { government } \\
\text { hospital bed }\end{array}$ & -0.034 & 0.012 & -2.811 & $0.009 * *$ \\
\hline & OLS, $N=30$, adj & sted $R$-squa & $e d=0.295$ & & \\
\hline
\end{tabular}

\subsection{2 $\mathrm{DR}(\mathrm{C})$}

For consistency, we present the results of identical exercises using an alternative measure of mortality from COVID-19, namely DR(C).

The results, in Table 6 , of the rank correlation undertaken are close to those in the case of CFR. There is rank correlation between HE/GDP and the death rate. However, there is also, such correlation between deaths and per capita income of the 
Table 4 Regression-mortality and private health infrastructuredependent variable is CFR

\begin{tabular}{|c|c|c|c|c|c|}
\hline \multicolumn{2}{|c|}{ Model } & \multicolumn{2}{|c|}{ Coefficients } & \multirow[t]{2}{*}{$t$} & \multirow[t]{2}{*}{ Sig } \\
\hline & & $B$ & Std. error & & \\
\hline \multirow[t]{3}{*}{1} & (Constant) & 1.685 & 0.204 & 8.275 & 0.000 \\
\hline & HE/GDP & -0.310 & 0.124 & -2.510 & $0.018^{*}$ \\
\hline & \multicolumn{5}{|c|}{ OLS, $N=30$, adjusted $R$-squared $=0.155$} \\
\hline \multirow[t]{5}{*}{2} & (Constant) & 1.570 & 0.275 & 5.706 & 0.000 \\
\hline & HE/GDP & -0.326 & 0.139 & -2.356 & $0.026^{*}$ \\
\hline & $\begin{array}{l}\text { Population } \\
\text { served by } \\
\text { one private } \\
\text { hospital }\end{array}$ & $7.857 \mathrm{E}-7$ & 0.000 & 1.187 & 0.246 \\
\hline & $\begin{array}{l}\text { Population } \\
\text { served by } \\
\text { one private } \\
\text { hospital bed }\end{array}$ & $9.449 \mathrm{E}-7$ & 0.000 & 0.410 & 0.685 \\
\hline & OLS, $N=30$, a & usted $R$-squa & $\mathrm{d}=0.137$ & & \\
\hline
\end{tabular}

$* p<0.05$

concerned state indicating that higher income is associated with higher mortality. In the regression analysis that followed, HE/GDP was statistically significant when entered as the sole independent variable but was no longer so when controls were added, for which see Table 7 . In a change from the case of CFR, now income and the level of urbanisation were significant.

Finally, as with CFR, the cross-plot of the death rate and public expenditure, in Fig. 2, shows a negative relation.

Our investigation, therefore, points in the direction of public health expenditure as a share of GDP having been a factor in the mortality from COVID-19. And, in the case of one of the measures of mortality, it rises with income, implying that the richer states of India have recorded a higher death rate.

\subsubsection{DR(E)}

The statistical analysis undertaken with CFR and DR(C) were replicated with DR(E) as the measure of mortality from COVID-19. However, the exercise drew a blank. The inter-state variation in DR(E) could not be explained either by health expenditure or infrastructure. This was in marked contrast to what was found to be the case for an earlier phase of the epidemic (see Balakrishnan \& Namboodhiry, 2021). For that phase, ending on October 3, 2021, this measure of mortality had turned out to be more closely related to health expenditure and health infrastructure than the other two measures, namely, CFR and DR(C). However, as seen in Fig. 3, when DR(E) is plotted against HE/GDP, the usual inverse relation between mortality and health expenditure holds. 


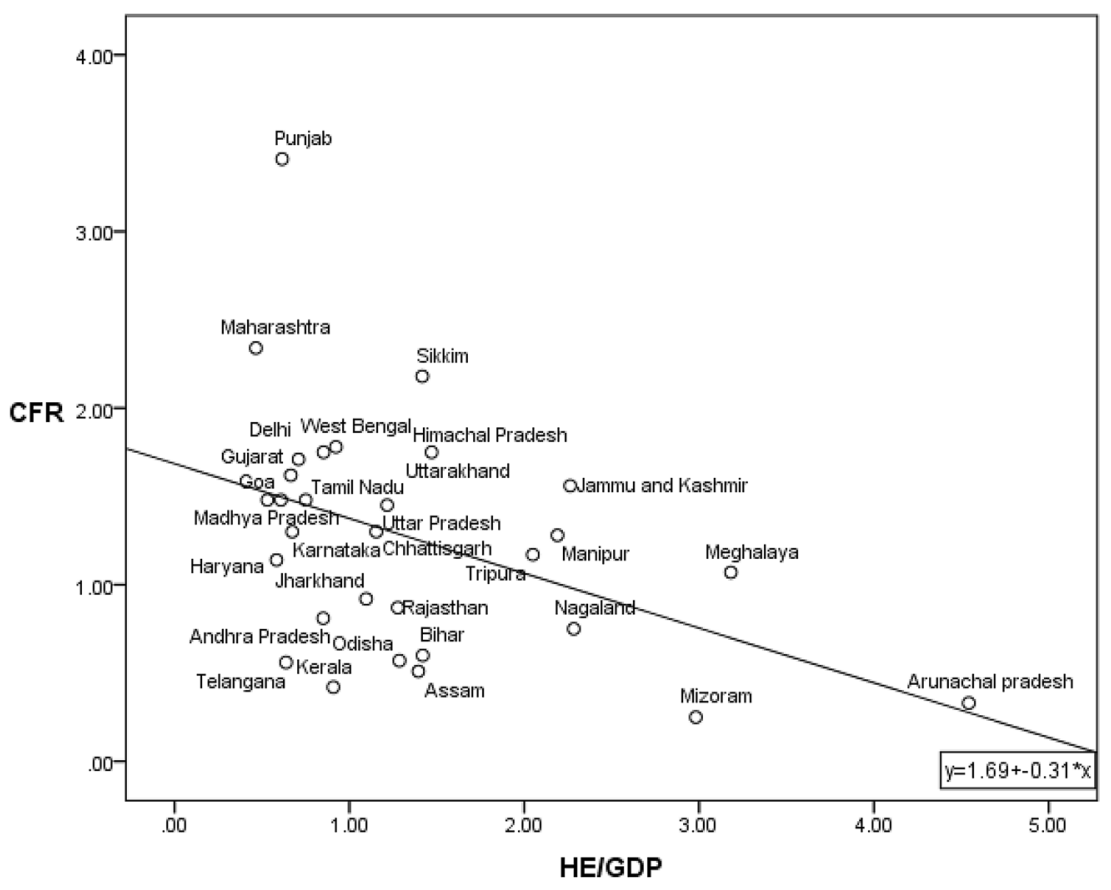

Fig. 1 Case fatality rate and public health expenditure as a share of GDP

Table 5 Regression-health expenditure with controlsdependent variable is CFR

\begin{tabular}{llllll}
\hline Model & \multicolumn{2}{l}{ Coefficient } & \multirow{2}{*}{ Sig } \\
\cline { 2 - 4 } & $B$ & \multicolumn{3}{l}{ Std. error } & \\
\hline 1 & (Constant) & 1.685 & 0.204 & 8.275 & 0.000 \\
& HE/GDP & -0.310 & 0.124 & -2.510 & $0.018^{* *}$
\end{tabular}

OLS, $N=30$, adjusted $R$-squared $=0.16$

\begin{tabular}{lllll}
2 (Constant) & 1.756 & 0.968 & 1.815 & 0.081 \\
HE/GDP & -0.313 & 0.182 & -1.717 & $0.098^{*}$ \\
Level of urbanisation & -0.001 & 0.009 & -0.117 & 0.907 \\
Population over 60 & -0.034 & 0.090 & -0.377 & 0.709 \\
Per capita income & $1.490 \mathrm{E}-6$ & 0.000 & 0.932 & 0.360 \\
OLS, $N=30$, adjusted $R$-squared $=0.09$ & & \\
\hline
\end{tabular}

$* p<0.10$

$* * p<0.05$ 
Table 6 Rank correlation: deaths per million

\begin{tabular}{llllll}
\hline Spearman's rho & \multicolumn{1}{l}{ HE/GDP } & $\begin{array}{l}\text { Per capita } \\
\text { public health } \\
\text { expenditure }\end{array}$ & $\begin{array}{l}\text { Per capita } \\
\text { income }\end{array}$ & $\begin{array}{l}\text { Population served } \\
\text { by one government } \\
\text { allopathic doctor }\end{array}$ & $\begin{array}{l}\text { Population } \\
\text { served by one } \\
\text { government } \\
\text { hospital }\end{array}$ \\
\hline $\begin{array}{l}\text { Correlation coef- } \\
\text { ficient }\end{array}$ & $-0.456^{*}$ & 0.167 & $0.614^{* *}$ & -0.220 & 0.151 \\
$\begin{array}{l}\text { Sig. (2-tailed) } \\
N\end{array}$ & 0.011 & 0.378 & 0.000 & 0.242 & 0.426 \\
& 30 & 30 & 30 & 30 & 30
\end{tabular}

*Significant at 0.05 level

** Significant at the 0.01 level

\subsubsection{A review of the results}

Our statistical analysis reveals that COVID-19 mortality in India, measured in different ways, is inversely related to public expenditure on health. On the other hand, it is not related to health infrastructure in the public sector. We have already provided a plausible explanation of this, which is that for a pandemic what is likely to matter more would be the response of the system as a whole rather than the presence of health infrastructure. This view is broadly in consonance with the views of other researchers in the field. Kandel et al. (2020) have developed an 'operational response index', which measures the capacity to provide health security in the context of the COVID-19 outbreak. In this index, they include the capacities to detect a health risk early, respond to it medically and to finance the associated operations (which they term the "enabling function"). It may be noted that these remain beyond the scope of infrastructure typically understood as revolving around hospitals. ${ }^{7}$ There is also feature that some populations, being more healthy, do not succumb to the disease even when they are infected. There is a role for primary healthcare in building such resistance. The existence of primary healthcare is not captured by the usual measures of physical infrastructure such as hospitals. Therefore, akin to the enabling role of finance in determining the effectiveness of the response during an epidemic, public spending on health can build resistance within a population by funding a primary healthcare system. When evaluating the results of our statistical analysis, the following comment of the Chief Scientist of the World Health Organisation may be noted: "Of the lessons I have learned over the last nine or ten months, the most important one is the significance of investing in public health and primary healthcare. Countries that invested in primary healthcare over the past decade or two are reaping the benefits now." (Swaminathan, 2020).

\footnotetext{
${ }^{7}$ When discussing the role of the NHS in combating the coronavirus in the UK the Chairman, Malcolm Grant', cited its "centralisation" having made it possible to achieve whatever it could (Grant, 2021). This may be interpreted as enabling the co-ordination necessary to address an epidemic. Significantly it would require funding. Grant quotes the figure of 27 percent of the UK government budget going to the NHS. This is extremely high by international standards. An international comparison is made later in this article.
} 
Table 7 Regression-health expenditure with controls-dependent variable is DR(C)

\begin{tabular}{|c|c|c|c|c|c|}
\hline \multirow[t]{2}{*}{ Mod } & & \multicolumn{2}{|c|}{ Coefficient } & \multirow[t]{2}{*}{$t$} & \multirow[t]{2}{*}{ Sig } \\
\hline & & $B$ & Std. error & & \\
\hline \multirow[t]{3}{*}{1} & (Constant) & 195.924 & 36.129 & 5.423 & 0.000 \\
\hline & HE/GDP & -49.638 & 21.923 & -2.264 & $0.032 *$ \\
\hline & OLS, $N=30$, adjusted $R-\mathrm{s}$ & $=0.125$ & & & \\
\hline \multirow[t]{6}{*}{2} & (Constant) & -78.617 & 119.550 & -0.658 & 0.517 \\
\hline & HE/GDP & -9.062 & 22.512 & -0.403 & 0.691 \\
\hline & Level of urbanisation (\%) & 2.719 & 1.107 & 2.456 & $0.021 *$ \\
\hline & Population over $60(\%)$ & 6.775 & 11.168 & 0.607 & 0.550 \\
\hline & Per capita income & 0.001 & 0.000 & 2.723 & $0.012 *$ \\
\hline & OLS, $N=30$, adjusted $R-\mathrm{s}$ & $=0.545$ & & & \\
\hline
\end{tabular}

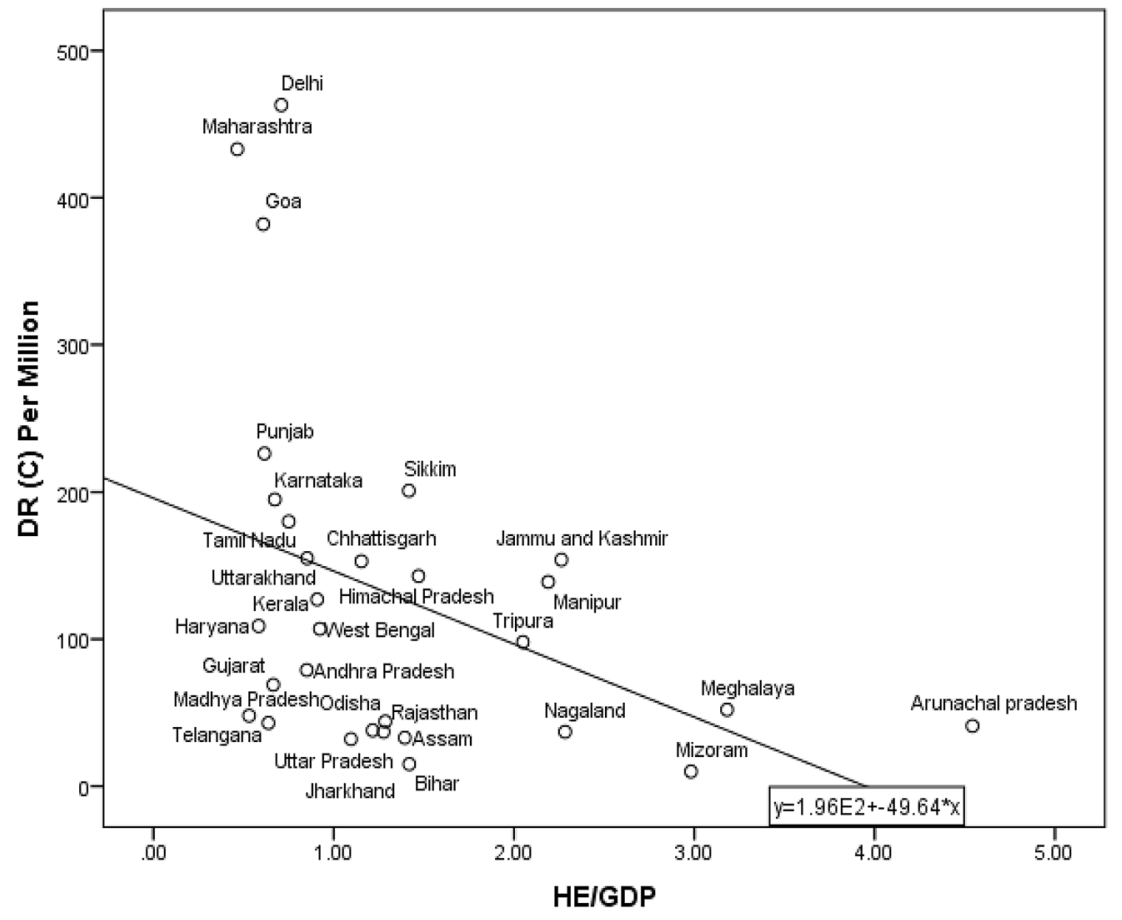

Fig. 2 DR (C) and public health expenditure as a share of GDP 


\section{The public funding of health in India}

Our investigation so far reveals an inverse relation between health spending and COVID-19 mortality across the states of India. Total expenditure given, a higher ratio of public health expenditure to GDP can be attained by raising the share of the budget allocated to health. That in India the health expenditure to GDP ratio is directly related to the share of the government budget devoted to health is seen in Fig. 4.

Noting the importance of the variable for the level of public health expenditure achieved, we now study the allocation for heath in the budgets of the state governments. According to the constitutional distribution of responsibilities between the central and state governments in India, Health is a state subject in India. Therefore, the expectation is that the state governments will bear the greater part of the public expenditure on health. In Table 8 are presented data on the share of their budgets that states allocated to health (henceforth HE/TE) in 2018-2019. The mean was 5.1 and the median was 4.9. While there is no absolute standard, it would appear that a share of less than $5 \%$ is unduly low given the state of health infrastructure in India. Half the states of India fall into this category. It is also noteworthy that close to half the states represented in the table, 12 to be precise spent very close to the same amount or more on the police than they did on health.

The largest among them, namely, Bihar, Jharkhand, Punjab, Haryana, UP, MP, Chhattisgarh and Maharashtra account for a very large share of the Indian population. Thus, for a significant section of India, the expenditure on law and order exceeds than on the health of the population. Apart from Maharashtra, these states are located in the north and the east of the country, and share a certain culture and history. It must be pointed out that some of the north-eastern states and the erstwhile state of J\&K have spending on the police exceeding spending on health. This may reflect the greater internal security threats that they face, but these states have high public spending in general, ensuring that health expenditure remains high in relation to GDP. In fact, every N-E state had HE/GDP greater than the Indian average. On the other hand, the eight mainland states mentioned above all have a health expenditure to GDP ratio lower than the national average, except for Bihar where the two were almost on par. We have already established the statistical relationship between health spending. Our confidence in the reliability of this finding is heightened when we note the case of Maharashtra, the state which had on March 31, 2021 registered the highest number of deaths and the second highest death rate. ${ }^{8}$ Maharashtra allocates less of its budget to health than the national average, which, when combined with low overall public expenditure in general, has yielded in a health expenditure to GDP ratio of less than half of one percent. Maharashtra is by far the richest state of India in terms of GDP. The consequence of the low spending on health is reflected in the state's health infrastructure; only 2 out of 30 Indian states have less hospitals, only three have less (allopathic) doctors and only eight have less hospital beds per head of population. ${ }^{9}$

Finally, we investigate whether states may be constrained by income in their public expenditure pattern. As may be seen in Fig. 5, the relation between state per

\footnotetext{
8 See Table 11 in the Appendix.

9 'National Health Profile Report' (2019).
} 


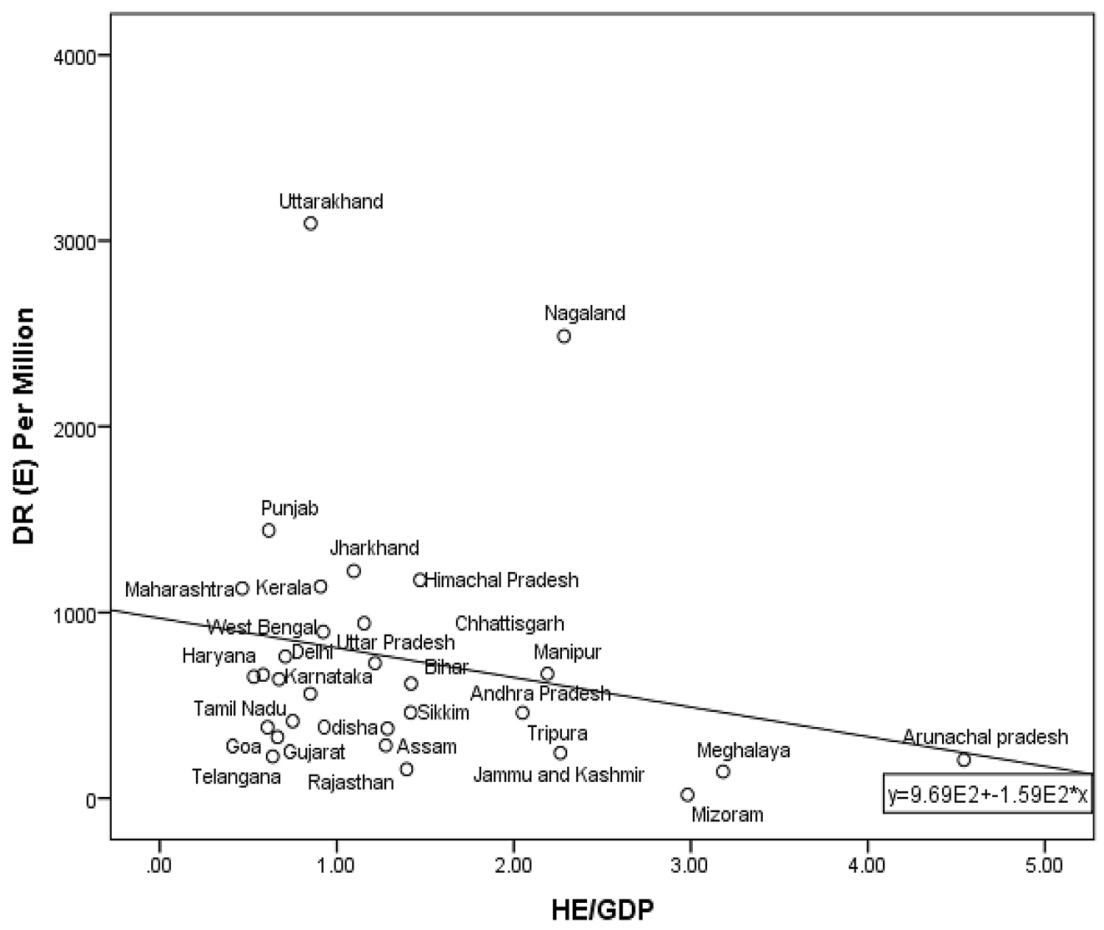

Fig. 3 DR (E) and public health expenditure as a share of GDP

income and health expenditure as a share of GDP is actually inverse, i.e. the richer states spend less of their gross domestic product on the public health sector. From a public policy point of view, it is significant that richer states devote a lower share of the income to public expenditure on health. It has the implication that lower spending is a policy choice. In India Health is a State subject, which implies that the states are expected to do the bulk of the providing for the health of their populations.

States do not have to spend on Defence, Communications including national highways and External Relations. Yet, some of them devote a lower share of their budget to health than the Centre. ${ }^{10}$ The significance of the ratio HE/TE is that it reflects the priority given to health by a government.

\footnotetext{
${ }^{10}$ Now that we know of the nature of the relationship between income and public health expenditure, we have a plausible explanation for the positive statistical relation between mortality and income across states. HE/GDP determines mortality, and the richer states have lower HE/GDP.
} 
Table 8 State-wise expenditure on public health in 2018-2019 (\%)

\begin{tabular}{|c|c|c|c|}
\hline State & HE/GDP & $\mathrm{HE} / \mathrm{TE}$ & $\begin{array}{l}\text { Police } \\
\text { expendi- } \\
\text { ture/TE }\end{array}$ \\
\hline Andhra Pradesh & 0.85 & 4.51 & 3.2 \\
\hline Assam & 1.39 & 6.46 & 5.54 \\
\hline Bihar & 1.42 & 4.73 & 4.84 \\
\hline Goa & 0.61 & 3.71 & 3.97 \\
\hline Gujarat & 0.66 & 5.49 & 2.77 \\
\hline Haryana & 0.58 & 3.63 & 3.74 \\
\hline Himachal Pradesh & 1.47 & 5.72 & 2.96 \\
\hline Karnataka & 0.67 & 4.42 & 2.7 \\
\hline Madhya Pradesh & 0.53 & 2.35 & 3.41 \\
\hline Maharashtra & 0.47 & 3.91 & 3.71 \\
\hline Odisha & 1.29 & 5 & 2.72 \\
\hline Rajasthan & 1.28 & 5.8 & 3.12 \\
\hline Telangana & 0.64 & 3.42 & 3.72 \\
\hline Uttar Pradesh & 1.22 & 4.63 & 4.34 \\
\hline Uttarakhand & 0.85 & 4.3 & 3.68 \\
\hline Arunachal Pradesh & 4.54 & 7.69 & 4.33 \\
\hline Chhattisgarh & 1.15 & 5.03 & 4.76 \\
\hline Delhi & 0.71 & 11.88 & 0 \\
\hline Jammu and Kashmir & 2.26 & 4.39 & 8.78 \\
\hline Jharkhand & 1.10 & 5.15 & 7.39 \\
\hline Kerala & 0.91 & 5.91 & 2.99 \\
\hline Manipur & 2.19 & 4.19 & 10.81 \\
\hline Meghalaya & 3.18 & 2.05 & 1.58 \\
\hline Mizoram & 2.98 & 6.03 & 6.51 \\
\hline Nagaland & 2.28 & 4.97 & 14.52 \\
\hline Punjab & 0.62 & 2.77 & 4.85 \\
\hline Sikkim & 1.42 & 7.17 & 6.32 \\
\hline Tamil Nadu & 0.75 & 5.14 & 2.94 \\
\hline Tripura & 2.05 & 7.36 & 9.53 \\
\hline West Bengal & 0.92 & 4.27 & 2.81 \\
\hline
\end{tabular}

For Jammu \& Kashmir and Manipur, the figures are 2019-2020 Accruals. Note that for Delhi, police expenditure is incurred by the central government

State of the State Finances report by PRS,www.prsindia.org and respective state budget documents for some states. See the data sources in Appendix 2 for details 


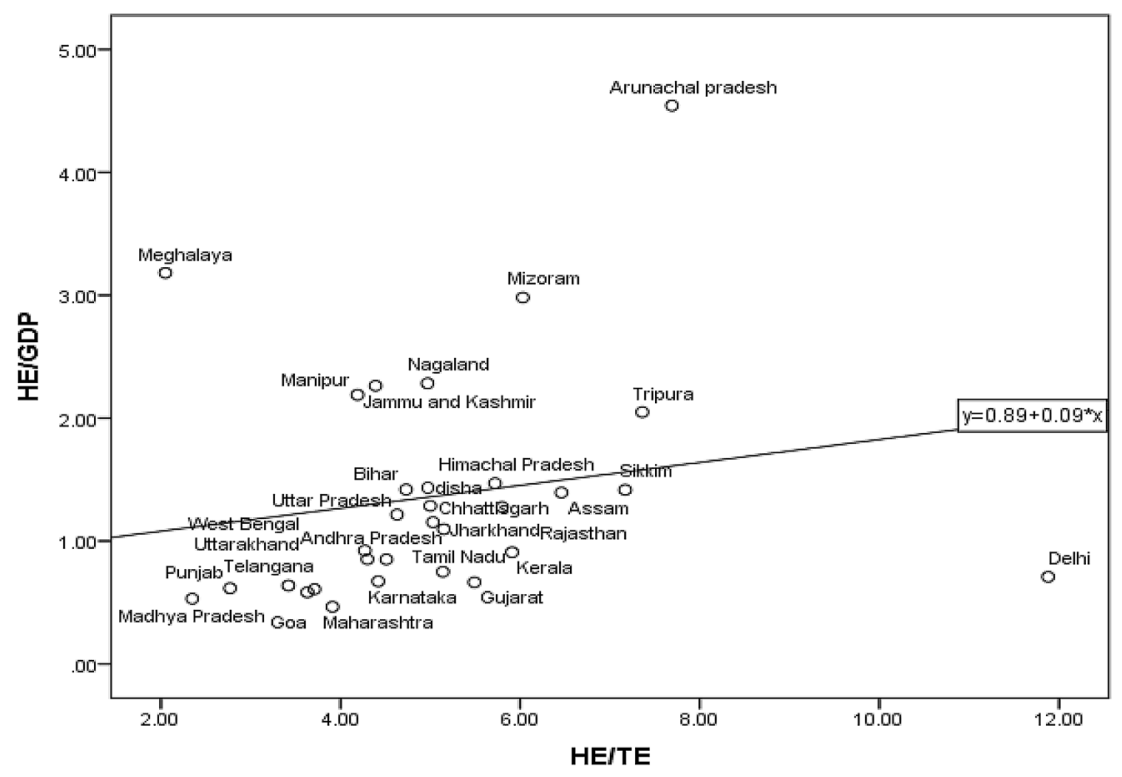

Fig. 4 Public health expenditure as a share of GDP and total expenditure

\section{COVID-19 mortality in India and the rest of Asia}

\subsection{South Asia}

A comparison of the mortality and public expenditure on health across South Asia is made possible with the data in Table 9. An inverse relation is evident. Maldives is clearly an outlier in that it bucks this pattern. Though it is the highest spender, it also is the country with the highest death rate. When it is removed from the sample, COVID-19 mortality data from South Asia corresponds to the pattern within India, confirming the importance of public expenditure on health. However, this comparison with South Asia indicates that health spending in relation to GDP does not fully account for the mortality. There are states with lower spending than India, namely, Bangladesh and Afghanistan, that record less deaths per million. These are exceptions to the rule, though. The four states, excluding Maldives, that have a higher HE/ GDP ratio all have a lower death rate than India's. Interestingly, they also devote a higher share of their budget to health. It must be remarked upon that two of them, namely, Nepal and Pakistan have a considerably lower GDP per capita than India. India just has chosen to spend less. 


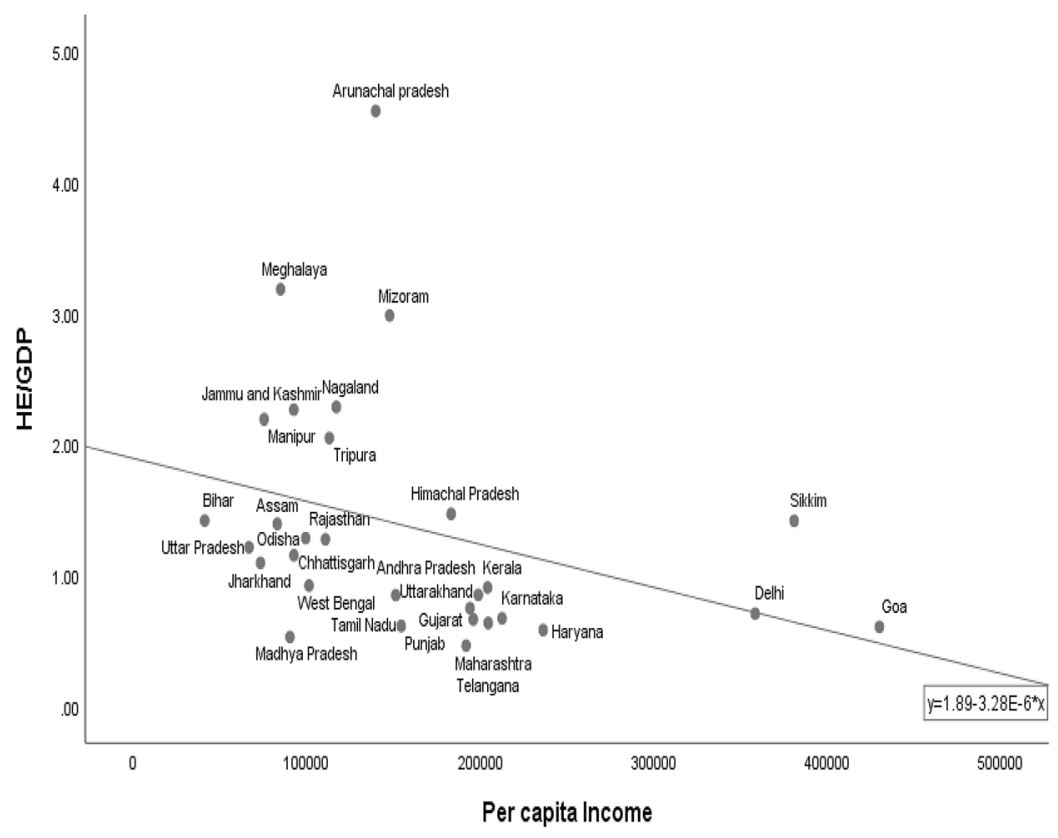

Fig. 5 State per capita income and health expenditure

Table 9 Public spending on health and COVID-19 mortality in South Asia

\begin{tabular}{lllllc}
\hline Country & $\begin{array}{l}\text { HE/GDP (percent) } \\
(2018)\end{array}$ & $\begin{array}{l}\text { HE/TE (percent) } \\
(2018)\end{array}$ & $\begin{array}{l}\text { GDP per capita } \\
\text { (current US\$) } \\
(2018)\end{array}$ & Total deaths & $\begin{array}{l}\text { Deaths } \\
\text { per } \\
\text { million }\end{array}$ \\
\hline Maldives & 6.65 & 21.44 & $10,276.93$ & 67 & 122 \\
India & 0.96 & 3.39 & 2005.86 & 162,927 & 117 \\
Nepal & 1.46 & 4.58 & 1038.65 & 3030 & 103 \\
Pakistan & 1.14 & 5.26 & 1482.3 & 14,530 & 65 \\
Afghanistan & 0.49 & 1.8 & 493.75 & 2484 & 63 \\
Bangladesh & 0.40 & 2.98 & 1698.35 & 9046 & 54 \\
Sri Lanka & 1.54 & 8.29 & 4080.56 & 568 & 26 \\
Bhutan & 2.43 & 7.61 & 3243.48 & 1 & Negli- \\
& & & & & gible \\
\hline
\end{tabular}

Total deaths are as on 31 March, 2021

Source: Mortality-https://ourworldindata.org/coronavirus-source-data; source cited is Johns Hopkins University

Population-https://www.worldometers.info/world-population/

GDP Per capita and Health expenditure- https://data.worldbank.org 


\subsection{Southeast Asia}

Taking the comparison further afield to southeast Asia, we find the divergence in public health expenditure between India and the countries of this region even greater. All the countries here devote a larger share of their budget to health than India does, even countries substantially poorer than India. Not surprisingly, health expenditure as a share of GDP is also higher, except for Myanmar. Most countries experienced a lower death rate than India did. As with Maldives in South Asia, there is an outlier here too. Indonesia devotes a large part of the government budget on health. Yet it records a death rate higher than that of poorer countries including India. Overall, data from this region accords with the proposition that public expenditure on health is a factor in COVID-19 mortality (Table 10).

Table 10 Public spending on health and COVID-19 mortality in South East Asia

\begin{tabular}{llllll}
\hline Country & $\begin{array}{l}\text { HE/GDP (percent) } \\
(2018)\end{array}$ & $\begin{array}{l}\text { HE/TE (percent) } \\
(2018)\end{array}$ & $\begin{array}{l}\text { GDP Per capita } \\
\text { (current US\$) } \\
(2018)\end{array}$ & Total deaths & $\begin{array}{l}\text { Deaths } \\
\text { per mil- } \\
\text { lion }\end{array}$ \\
\hline Indonesia & 1.42 & 8.51 & 3893.84 & 40,858 & 149 \\
Philippines & 1.44 & 6.6 & 3252.09 & 13,297 & 121 \\
Myanmar & 0.71 & 3.49 & 1418.17 & 3206 & 59 \\
Malaysia & 1.92 & 8.47 & $11,377.45$ & 1272 & 39 \\
Singapore & 2.25 & 15.28 & $66,188.77$ & 30 & 5 \\
Thailand & 2.89 & 15.03 & 7295.47 & 94 & 1 \\
Cambodia & 1.28 & 5.21 & 1512.12 & 11 & 1 \\
Vietnam & 2.7 & 9.35 & 2566.59 & 35 & Negligible \\
\hline
\end{tabular}

Deaths are as on 31 March, 2021

Source: Mortality -https://ourworldindata.org/coronavirus-source-data; source cited is Johns Hopkins University

Population-https://www.worldometers.info/world-population/

GDP Per capita and Health expenditure- https://data.worldbank.org

\section{Conclusion}

We have investigated the role of public health policy in determining mortality from COVID-19 in India. Statistical analysis using data for the states of India showed evidence of the impact of one aspect of this policy, namely, health expenditure. The impact of health infrastructure was far less strong. A plausible interpretation of this finding be that the availability of infrastructure is subsumed under health spending. Moreover, infrastructure is likely to matter as a complex, while statistically we consider their impact individually due to 
the form of the data. In our view, the attempt to construct an infrastructure index for the purpose of statistical analysis cannot but be ad hoc, and therefore , unsatisfactory. Having established the role of public health expenditure, we proceeded to analyse the level of health expenditure pattern. Two stylised facts maybe noted. First, public health expenditure as a share of GDP shows a variation, with the richer states spending less. This implies that the level of public health expenditure is a public policy choice rather than being constrained by income or capacity. It is reflected in the feature that states accounting for a large part of India spend more on the police than they do on health. Second, the average budgetary allocation for health, at five percent, may be judged to be far too low given the current state of public health capacity in the country. In an international comparison, though confined to Asia, it is seen that India devotes less to health in the public sector, in some cases far less. As the mortality from COVID-19 in India is higher than in most countries in south and southeast Asia, it would be reasonable to infer that this reflects the gap in public spending. The inescapable conclusion from our analysis is that at least some of the COVID-19 mortality in India is related to the health policy that has been pursued. Arguably, then, some of the death was avoidable. Looking ahead to a time when the pandemic has abated, we can see that health security can be assured in India only when the states have scaled up their health expenditure very substantially. The link between state per capita income and public spending on health on the one hand and health expenditure and public health spending and mortality on the other predict that states that privilege growth over public health endanger life during an epidemic.

\section{Appendix: Data}

See Tables 11, 12 . 
Table 11 The case fatality rate on March 31, 2021

\begin{tabular}{|c|c|c|c|}
\hline State & Cases (16.03.2021) & Deaths (31.03.2021) & CFR \\
\hline Andhra Pradesh & $892,008.00$ & 7213.00 & 0.81 \\
\hline Assam & $217,817.00$ & 1104.00 & 0.51 \\
\hline Bihar & $263,051.00$ & 1574.00 & 0.60 \\
\hline Goa & $56,006.00$ & 829.00 & 1.48 \\
\hline Gujarat & $279,097.00$ & 4510.00 & 1.62 \\
\hline Haryana & $275,557.00$ & 3147.00 & 1.14 \\
\hline Himachal Pradesh & $59,750.00$ & 1045.00 & 1.75 \\
\hline Karnataka & $961,204.00$ & $12,541.00$ & 1.30 \\
\hline Madhya Pradesh & $269,391.00$ & 3977.00 & 1.48 \\
\hline Maharashtra & $2,329,464.00$ & $54,422.00$ & 2.34 \\
\hline Odisha & $338,258.00$ & 1921.00 & 0.57 \\
\hline Rajasthan & $323,220.00$ & 2813.00 & 0.87 \\
\hline Telangana & $301,522.00$ & 1697.00 & 0.56 \\
\hline Uttar Pradesh & $605,441.00$ & 8800.00 & 1.45 \\
\hline Uttarakhand & $97,866.00$ & 1713.00 & 1.75 \\
\hline Arunachal Pradesh & $16,840.00$ & 56.00 & 0.33 \\
\hline Chhattisgarh & $317,974.00$ & 4131.00 & 1.30 \\
\hline Delhi & $644,064.00$ & $11,016.00$ & 1.71 \\
\hline Jammu and Kashmir & $127,734.00$ & 1990.00 & 1.56 \\
\hline Jharkhand & $120,695.00$ & 1113.00 & 0.92 \\
\hline Kerala & $1,092,324.00$ & 4606.00 & 0.42 \\
\hline Manipur & $29,313.00$ & 374.00 & 1.28 \\
\hline Meghalaya & $13,997.00$ & 150.00 & 1.07 \\
\hline Mizoram & 4439.00 & 11.00 & 0.25 \\
\hline Nagaland & $12,225.00$ & 92.00 & 0.75 \\
\hline Punjab & $199,573.00$ & 6813.00 & 3.41 \\
\hline Sikkim & 6184.00 & 135.00 & 2.18 \\
\hline Tamil Nadu & $860,562.00$ & $12,700.00$ & 1.48 \\
\hline Tripura & $33,440.00$ & 392.00 & 1.17 \\
\hline West Bengal & $578,598.00$ & $10,327.00$ & 1.78 \\
\hline
\end{tabular}

Case fatality rate $=$ Total deaths $(t) /$ Total confirmed $(t-15)$, accordingly confirmed COVID-19 figures are as on 16 March 2021 and deaths as on 31 March 2021

Source: COVID-19 data is from www.MyGov.in. See the data sources for details 
Table 12 The crude death rate DR [C] and the estimated death rate DR [E]

\begin{tabular}{|c|c|c|c|c|c|c|}
\hline State & Deaths & $\begin{array}{l}\text { DR }(C) \text { per } \\
\text { million }\end{array}$ & $\begin{array}{l}\text { Multi- } \\
\text { plication } \\
\text { factor }\end{array}$ & $\mathrm{DR}(\mathrm{E})$ & $\begin{array}{l}\text { Projected popula- } \\
\text { tion } 2020 \text { (in } \\
\text { millions) }\end{array}$ & $\begin{array}{l}\text { DR (E } \\
\text { per mil- } \\
\text { lion) }\end{array}$ \\
\hline Andhra Pradesh & 7213 & 79 & 7.09 & 51,140 & 90.94 & 562 \\
\hline Assam & 1104 & 33 & 4.79 & 5288 & 33.85 & 156 \\
\hline Bihar & 1574 & 15 & 42.5 & 66,895 & 108.37 & 617 \\
\hline Goa & 829 & 382 & 1 & 829 & 2.17 & 382 \\
\hline Gujarat & 4510 & 69 & 4.78 & 21,558 & 65.53 & 329 \\
\hline Haryana & 3147 & 109 & 6.13 & 19,291 & 29.00 & 665 \\
\hline $\begin{array}{r}\text { Himachal } \\
\text { Pradesh }\end{array}$ & 1045 & 143 & 8.22 & 8590 & 7.31 & 1175 \\
\hline Karnataka & 12,541 & 195 & 3.29 & 41,260 & 64.41 & 641 \\
\hline Madhya Pradesh & 3977 & 48 & 13.5 & 53,690 & 82.13 & 654 \\
\hline Maharashtra & 54,422 & 433 & 2.61 & 142,041 & 125.71 & 1130 \\
\hline Odisha & 1921 & 44 & 8.55 & 16,425 & 43.76 & 375 \\
\hline Rajasthan & 2813 & 37 & 7.76 & 21,829 & 76.75 & 284 \\
\hline Telangana & 1697 & 43 & 5.22 & 8858 & 39.36 & 225 \\
\hline Uttar Pradesh & 8800 & 38 & 19.12 & 168,256 & 231.42 & 727 \\
\hline Uttarakhand & 1713 & 155 & 19.92 & 34,123 & 11.02 & 3094 \\
\hline $\begin{array}{c}\text { Arunachal } \\
\text { Pradesh }\end{array}$ & 56 & 41 & 5.04 & 282 & 1.36 & 206 \\
\hline Chhattisgarh & 4131 & 153 & 6.17 & 25,488 & 27.06 & 942 \\
\hline Delhi & 11,016 & 463 & 1.65 & 18,176 & 23.81 & 763 \\
\hline $\begin{array}{c}\text { Jammu and } \\
\text { Kashmir }\end{array}$ & 1990 & 154 & 1.58 & 3144 & 12.88 & 244 \\
\hline Jharkhand & 1113 & 32 & 38.76 & 43,140 & 35.27 & 1223 \\
\hline Kerala & 4606 & 127 & 9.01 & 41,500 & 36.41 & 1140 \\
\hline Manipur & 374 & 139 & 4.83 & 1806 & 2.69 & 670 \\
\hline Meghalaya & 150 & 52 & 2.75 & 413 & 2.88 & 143 \\
\hline Mizoram & 11 & 10 & 1.83 & 20 & 1.10 & 18 \\
\hline Nagaland & 92 & 37 & 66.94 & 6158 & 2.47 & 2486 \\
\hline Punjab & 6813 & 226 & 6.37 & 43,399 & 30.10 & 1442 \\
\hline Sikkim & 135 & 201 & 2.3 & 311 & 0.67 & 461 \\
\hline Tamil Nadu & 12,700 & 180 & 2.31 & 29,337 & 70.61 & 415 \\
\hline Tripura & 392 & 98 & 4.67 & 1831 & 3.98 & 460 \\
\hline West Bengal & 10,327 & 107 & 8.38 & 86,540 & 96.63 & 896 \\
\hline
\end{tabular}

Deaths are as on $31 \mathrm{March}$. The multiplication factor, being the adjustment made to the reported deaths, is discussed in Sect. 2 above

Source: The multiplication factor is taken from Shewade and Parameswaran (2020). 


\section{Data sources \\ COVID-19: cases and deaths}

'COVID-19 State-wise status'. (2021, April 01). MyGov.In.

https://www.mygov.in/corona-data/covid19-statewise-status

\section{GDP and per capita income}

Ministry of Statistics and Program Implementation. (07.10.20). State Domestic Products and Other Aggregates, 2011-2012 series [Dataset]. Directorate of Economics \& Statistics of respective State Governments.

http://www.mospi.gov.in/data

\section{Public expenditure on health}

Analysis of State Budgets. PRS Legislative Research. Retrieved September 7, 2020, from

https://www.prsindia.org/parliamenttrack/budgets/state?field_state_tid=All\& field_session_year_value[value]\&page $=1$

For the North-eastern states, Goa, and Jammu and Kashmir the data 2018-2019 are from the respective state budget documents. All data are for the year 2018-2019.

\section{Public health infrastructure}

Central Bureau of Health Intelligence (2019a). National Health Profile 2019 (no. 14), Government of India, http://www.cbhidghs.nic.in/showfile.php?lid=1147

\section{Private health infrastructure}

Kapoor, G., A.Sriram, J.Joshi, A.Nandi, R. Laxminarayan (2021) 'COVID-19 in India: State-wise estimates of current hospital beds, intensive care unit (ICU) beds and ventilators', Centre for Disease Dynamics, Economics and Policy. Princeton University.

https://cddep.org/publications/covid-19-in-india-state-wise-estimates-of-currenthospital-beds-icu-beds-and-ventilators/

\section{Population}

State-wise population: Central Bureau of Health Intelligence (2019b). National Health Profile 2019 (no. 14), Government of India. http://www.cbhidghs.nic.in/showfile.php?lid=1147 
Telangana Population. (no date). http://www.populationu.com/. Retrieved September 8,2020 , from.

http://www.populationu.com/in/telangana-population

Population over 60: Ministry of Statistics and Program Implementation. (2016, February). Elderly in India Report 2016. Government of India.

http://mospi.nic.in/sites/default/files/publication_reports/ElderlyinIndia_2016.pdf Urbanisation: Office of the Registrar General and Census Commissioner. (2011). Census 2011 Trends in Urbanization, Government of India: urbanisation is measured as the proportion of the population living in areas defined as urban;

https://censusindia.gov.in/2011-prov-results

Funding No funding.

Declarations

Conflict of interest The authors declare that they have no conflict of interest.

\section{References}

Balakrishnan, P., \& Namboodhiry, S. K. (2021). The inter-state variation in Mortality from COVID-19 in India. Economic and Political Weekly, LVI(6), pp 36-43. https://www.epw.in/journal/2021/6/speci alarticles/interstate-variation-mortality-covid-19-india.html. Accessed 28 Mar 2021.

Bonanad, C., García-Blas, S., Tarazona-Santabalbina, F., Sanchis, J., Bertomeu-González, V., Fácila, L., Ariza, A., Núñez, J., \& Cordero, A. (2020). The effect of age on mortality in patients with COVID19: A meta-analysis with 611,583 subjects. Journal of the American Medical Directors Association, 21(7), 915-918. https://doi.org/10.1016/j.jamda.2020.05.045

Coşkun, H., Yıldırım, N., \& Gündüz, S. (2020). The spread of COVID-19 virus through population density and wind in Turkey cities. Science of the Total Environment, 751, https://doi.org/10.1016/j.scito tenv.2020.141663.

Grant, M. (2021) 'Second wave: How NHS saved UK, lessons for India in a Viral War', interview with Shoma Choudhury. https://www.youtube.com/watch?v=VLMr0DOq2CA; Accessed 21 May 2021.

Kandel, N., Chungong, S., Omaar, A., \& Xing, J. (2020). Health security capacities in the context of COVID-19 outbreak: An analysis of International Health Regulations annual report data from 182 countries. The Lancet, 395(10229), 1047-1053. https://doi.org/10.1016/s0140-6736(20)30553-5

Mallapaty, S. (2020). The coronavirus is most deadly if you are older and male-new data reveal the risks. Nature, 585(7823), 16-17. https://doi.org/10.1038/d41586-020-02483-2

Shewade, D.H., \& Gopal Parameswaran, G. (2020). COVID-19 deaths maybe higher than reported. The Hindu. https://www.thehindu.com/opinion/op-ed/covid-19-deaths-are-not-as-low-asreported/artic le32310814.ece. Accessed 13 Apr 2021.

Swaminathan, S. (2020). The many lessons from COVID-19. The Hindu. https://www.thehindu.com/ opinion/op-ed/the-many-lessons-from-covid-19/article32947329.ece. Accessed 28 Apr 2021.

Publisher's Note Springer Nature remains neutral with regard to jurisdictional claims in published maps and institutional affiliations. 